\title{
Perception of an adaptation to climate change by the maize farmers of Baitadi District, Nepal
}

\author{
Rajendra Bam ${ }^{1}$, Raksha Pandey ${ }^{2}$, Keshav Bhusal ${ }^{3}$
}

\author{
${ }^{1}$ Department of Agri-Botany and Ecology, Tribhuwan University, Kathmandu, Nepal \\ ${ }^{2}$ Department of Agriculture, IAAS, Tribhuwan University, Nepal \\ ${ }^{3}$ Department of Agribusiness and Economics, Agriculture and Forestry University, Chitwan, Nepal
}

\begin{abstract}
A survey research was conducted in Dilasaini and Dogadakedar rural municipalities of Baitadi district, Nepal to study the perception of and adaption to climate change by the maize farmers. Thirty households from each local levels were selected randomly. Primary data was collected through household survey with pre-tested interview schedule, direct observation and focus group discussion. Descriptive statistics along with binary logistic regression model were used for analysis of the data. The total population was dominated by brahmin and chhetri (89.67\%) followed by occupational caste (10\%) community with economically active population 61.68 percent. The major occupation was agriculture (65\%). Farmers were gradually diverted towards other livelihood options like remittance, off farm activities, beside agriculture. 68.33 percent of total households were dominated by male while only 31.67 percent were female dominated. Majority of farmers (91\%) perceived changes in climatic affected the maize production. Most of the farmers reported frequent drought followed by off seasonal rain. Almost 78.3 percent households preferred radio for the information related to climate change. Age and agriculture as the major source of income were found significantly affecting the knowledge on climate change negatively. Individuals with agriculture as the major income possess comparatively less knowledge on climate change as compared to their younger counterfeit. The existing climate change coping strategies depends heavily on the traditional knowledge. Promoting the minors with precise information, skills and knowledge, garnered through site-specific researches along with holistic mitigating approaches and scaling up traditional knowledge on climate change impacts and adaptation strategy is sure to pave a way forward to climate resilience community.
\end{abstract}

Keywords-Adaptation strategies, Climate change, Maize production, Perception, Vulnerability.

\section{INTRODUCTION}

Agriculture continues to be extremely important business in case of Nepal which contributes $32.6 \%$ to national GDP and provides employment to $65.6 \%$ of population (MoAD, 2015). The stat shows the overall development of the national is impossible without development of this very sector. Agriculture is not only the source of bread and butter but a major source of raw materials to the agrobased industries in Nepal. Agriculture sector contributes more than $60 \%$ to the total national export (CBS, 2014). Among the harvests of staple crops; maize is one of the most important crop for mid hill farmers. Climate change is hitting on agriculture mostly developing country like Nepal.

The air temperature near earth surface rose by $0.74^{\circ} \mathrm{C}$ from 1906 to 2005 and scientists estimated it could be increased as much as $6.4^{\circ} \mathrm{C}$ on average during the $21^{\text {st }}$ century (IPCC, ISSN: 2456-1878

https://dx.doi.org/10.22161/ijeab.55.12
2007). Nepal's temperature has been reported to be rising at a rate of $0.06{ }^{\circ} \mathrm{c}$ per year as a result of climate change (Dahal, 2006). This could affect crop production as each plant species are most productive or can survive/tolerate only within a certain range of temperature. Climate change has also been linked to changes in precipitation patterns in the country, particularly, the monsoon season. The monsoon season has been shortened with decline in total annual precipitation, and increase in frequency of heavy/intense storms (often leading to flooding) in rainy season as well as droughts in winter season (Pokhrel \& Pandey, 2011). Approximately $64 \%$ of the cultivated areas in Nepal are heavily dependent on monsoon rainfall and changes in the time and duration of this monsoon rainfall could adversely affect the agricultural production significantly (Lohani, 2007). Maize is produced on nearly 100 million hectares in developing countries, with almost 
$70 \%$ of the total maize production in the developing world coming from low and lower middle income countries (FAOSTAT, 2010). Pant (2012) on the other hand has reported that climate change affected rice and barley production negatively in the country thus, increased food insecurity. Furthermore, increase in disease and pest infestation in crops due to changes in seasonal patterns have been linked with not just decline in production but even extinction of some local crop varieties and natural vegetation (Malla, 2008). Using crop production and meteorological records, Thomson et al., (1966) showed that a $6{ }^{\circ} \mathrm{C}$ increase in temperature during the grain filling period resulted in a $10 \%$ yield loss in the US Corn Belt. A later study in the same region showed maize yields to be negatively correlated with accumulated degrees of daily maximum temperatures above $32{ }^{\circ} \mathrm{C}$ during the grain filling period (Dale, 1983).

Far-western Nepal is one of the most vulnerable to vagaries of the climate change. Persistent food crises in the region are the reminders of the continuing vulnerability of the region to the effect of climate conditions. This is in large measure due to weak institutional capacity, low paying capacity of the farmers, limited engagement in environmental and adaption issues, and a lack of priority to the sector. This region is quite virgin incase of research study and findings. Those working in the sector of climate change are just providing their service based upon some assumption and eyed seen symptoms. This research tried to drag out the perception and knowledge of the local maize farmers about climate and climate change and measured adapted by them to cope with the problem.

Nepal has various types of agriculture zones in which agricultural sectors damaged in Terai and more in hills and mountain due to increase in temperature (Malla, 2008). Increased concentration of $\mathrm{CO}_{2}$ causes vigorous growth of the crops which ultimately lead to reduce level of organic carbon from soil, soil micronutrients and enhanced activity of micro-organisms (Malla, 2003). Some of the farmers are happy with the changes; for example, Farmers of Manang and Mustang districts have noticed improved apple sizes in recent years (Dahal, 2005). There will be gains in some crops in some regions of the world; the overall impacts of climate change on agriculture are expected to be negative, threatening global food security (IFPRI, 2009).

Adaption to climate change may include many measures, one of these is policy reform to adjust/ adapt to climate change. Individuals, households, government or any stakeholders can implement effective adaption strategies to adjust the climate variations and uncertainties based on the resources availability and economic and social conditions.
Nepal gradually adopting new cropping system and changed the cropping system from rice-wheat-maize to fruits and plantation crop like banana which is less sensitive to climate change (Gurung, 2008). Promotion of rain water harvesting in mountainous region can be adoptive strategy for existing as well as projected impacts of drought (MOPE, 2004). Sloping Agriculture Land Technology and eco-friendly vegetable production in Jugedi khola watershed, kabilash helped to cope with impacts change in that area (Ghimire, 2008). Economics diversification can also be an important adaption strategy for the developing countries to reduce dependence on climate sensitive resources (UNFCC, 2007). Zero tillage is an emerging coping for climate change that reduces $27 \%$ green house gases emission (AEU, 2010 and 2011).

The study outcomes helped to streamline approaches for achieving Millennium Development Goals (MDGs) specially the poverty eradication, environmental sustainability goals, provides strategy to cope climate change, etc. Climate change induced flood, landslide, soil erosion, erratic rainfall, drought, etc resulting increased risk and uncertainty, however the alteration in the cropping pattern, loss of the local and indigenous variety and use of the hybrid and resistant variety of maize are some of the local strategies in coping the climate change. Thus, this study aimed to estimate the impact of climate change on Maize production in the Baitadi. This study will contribute toward existing knowledge gap and help researchers and policy makers to respond to climate change by adjusting agricultural and environmental policies and practices as needed. This study explores the perception of Farmer's on climate change and its adaption strategies and reducing the vulnerability of the climate change impacts

\section{MATERIALS AND METHODS}

The study was conducted in June-July, 2018 on Baitadi district of Nepal. Dilasiani and Dogadakedar rural municipalities were purposively selected in consultation with community level, district level organization and DADO where maize has been the major staple cereal crops. Pre-testing of interview schedule was done before the field survey by administering the designed interview schedule to the 8 respondents nearby the study area to assure the research design and preliminary information regarding socio-cultural, topographical, and institutional features. Altogether 60 households, farmers with at least 10 years of settlement, thirty from each rural municipality (representing all the wards possible) were selected randomly assuring the availability of relevant information regarding the past trends of climate hazards. Interview 
schedule was used to collect the primary information. Additionally, 5 focus group discussion and 5 key informant interviews were conducted to generate the general status and distribution of maize production, and effect of climate change on maize production. The major variables included in interview schedule were socioeconomic characteristics, farm characteristics, livelihood options, farmers' perception, their adaption strategies, and crop production trends. The study concentrated on both primary and secondary data. Climatic data related to rainfall, temperature, $\mathrm{RH}$ and other required parameters were collected from the meteorological station situated at Baitadi in addition to data from various published journals, research articles, proceeding of various NGOs and INGOs, reports of Distrct Agriculture, Development Office (DADO), District Development Committee (DDC), National Agriculture Research Council (NARC), Central Bureau of Statistics (CBS), local leaders and working agencies were the sources of secondary information. The available 10 year climatic data was analyzed to determine the climatic suitability and hazard for maize production in the study area.

\section{a. Methods and techniques of data analysis}

Data entry and analysis were done by using Statistical Package for Social Science (SPSS V.16) and Microsoft Excel. The local units of measurements were corrected into scientific one. Both descriptive and analytical methods were used to analyze the data. Both qualitative and quantitative analyses were done with regards to the objectives.

\section{i. Qualitative analysis}

Qualitative data were analyzed by using the both descriptive and analytical statistics. Qualitative information from the survey questionnaire was quantified with the appropriate scaling method. Farmer's perception was mapped using multiple ranking matrix and likert scale.

\section{Quantitative analysis}

Socio-economic and farm characteristics of the respondents like family size, age, occupational pattern, change in size of holding, size of the irrigated holding, distribution of economically active population were described by using simple descriptive statics like frequency, percentage, mean and standard deviation. Impacts and perception of Farmers on the change of climate variables over the time and their adaption strategies were studied by estimating frequency, frequency, percentage, charts and diagram.

\section{Analytical statistics}

Changes in the trend of area allocation over the time and productivity changes obtained from both primary and secondary sources were analyzed using trend line estimation in Microsoft Excel.

Climate change impact analysis

The log linear regression analysis was done to study the effect of precipitation and temperature on productivity of Maize.

$$
\begin{gathered}
\ln P_{t}=a+b_{1} \ln A_{t}+b_{2} \ln A M_{X} T_{t}+ \\
b_{3} \ln A M n T_{t}+b_{4} \ln S R F_{t} \\
\text { Equation } 1
\end{gathered}
$$

Where,

$$
\begin{aligned}
& P_{t}=\text { productivity of Maize }\left(\text { tonha }^{-1}\right) \text { in } \mathrm{t}^{\text {th }} \text { year } \\
& A_{t}=\text { area under Maize in } \mathrm{t}^{\text {th }} \text { year }
\end{aligned}
$$

$A M_{X} T_{t}=$ seasonal average of maximum temperature for Maize in $\mathrm{t}^{\text {th }}$ year

$$
A M n T_{t}=\text { seasonal average of minimum }
$$

temperature for Maize in $\mathrm{t}^{\text {th }}$ year

$$
S R F_{t}=\text { seasonal rainfall for Maize in } \mathrm{t}^{\text {th }} \text { year. }
$$

\section{RESULTS AND DISCUSSION}

\section{i. General characteristics of study area}

The study district, Baitadi, covered an area of 1,519 Sqr. $\mathrm{km}$ and had total population of 250,898 (CBS, 2011). The Baitadi districts entail 4 municipalities and 6 Rural Municipalities. Baitadi falls into the farthest western regional districts of Nepal touching Jhulaghat, India, to its boarder. Table 1 illustrates that the majority of the household head were male $(31.67 \%)$ which is in line with the national status. Similarly, overall average age of the household head were 44 years with minimum of 21 years and maximum of 70 years. Majority of the household head were under economically active age group. Overall sample had a higher literacy rate $(75 \%)$ while, illiteracy being just $25 \%$. The average year of schooling was 8.05 and the maximum year of schooling was 18 and minimum was zero. Joint type of family was dominating in both the rural municipality and was followed by nuclear one.

The members of age group 15-60 was maximum (68\%) followed by members of age group below the 15 years i.e. $32.84 \%$ and members of age group above 60 years i.e. $5.4 \%$. In the both Rural Municipality the maximum average family size was 19 while minimum family size was 3 and the average family size was 7.91. The major 
occupations of family members were agriculture contributing $65 \%$ in both the rural municipality, followed by the trade/business $(25 \%)$, service $(5 \%)$, wage $(3.33 \%)$ and remittance $(1.67 \%)$ respectively.

The total land holding area was 15.33 ropani $^{1}$. Average owned land was 14.2 ropani which was higher in comparison to the average land rented-out i.e. 0.73 ropani and rented-in i.e. 0.67 ropani respectively. The maximum land holding was 80 ropani while minimum land was 1 ropani and the average of total land was 15.53 ropani. The maximum cultivated land of both the Rural municipality of total land was 50 ropani and minimum cultivated land was 1 ropani. The average maize cultivated land over 60 households was 5.81 ropani. Among them maximum total maize cultivated land was 30 ropani and minimum 1 ropani land.

The average income from agriculture was NRs 40541.67 while average income from maize was NRs 18991.67.The maximum and minimum income from agriculture was NRs 150000 and NRs 1500 respectively. Similarly, the maximum and minimum income from maize only was NRs 90000 and 1000 respectively.

Table 1 Socio-economic characteristics

\begin{tabular}{|l|l|l|l|l|}
\hline $\begin{array}{l}\text { Socio- } \\
\text { economic } \\
\text { characterist } \\
\text { ics }\end{array}$ & $\begin{array}{l}\text { Overall } \\
\text { average } \\
\text { Gender of HHH }\end{array}$ & $\begin{array}{l}\text { Maxim } \\
\text { um }\end{array}$ & $\begin{array}{l}\text { Minimu } \\
\text { m }\end{array}$ & SE \\
\hline Male & $41(68.33)$ & & & \\
\hline Female & $19(31.67)$ & - & - & - \\
\hline $\begin{array}{l}\text { Age } \\
\text { household } \\
\text { head }\end{array}$ & 43.48 & 70 & 21 & 1.52 \\
\hline Ethnicity & \multicolumn{5}{|l|}{} & \\
\hline Brahmin & $17(28.33)$ & - & - & - \\
\hline Chhetri & $37(61.67)$ & - & - & - \\
\hline Janjati & $0(0.0)$ & - & - & - \\
\hline Dalit & $6(10.00)$ & - & - & - \\
\hline Education status & $15(25.00)$ & - & - & - \\
\hline $\begin{array}{l}\text { Total } \\
\text { illiterate }\end{array}$ & & & - & \\
\hline $\begin{array}{l}\text { Total } \\
\text { literate }\end{array}$ & $45(75.00)$ & - & & \\
\hline
\end{tabular}

11 Hectare $=20$ Ropani

2 Individuals who cannot read and write

ISSN: 2456-1878

https://dx.doi.org/10.22161/ijeab.55.12

\begin{tabular}{|c|c|c|c|c|}
\hline $\begin{array}{l}\begin{array}{l}\text { Average } \\
\text { year of } \\
\text { schooling }\end{array} \\
\end{array}$ & 8.05 & 18 & 0 & 0.55 \\
\hline \multicolumn{5}{|l|}{ Type of family } \\
\hline Nuclear & $19(31.67)$ & - & - & - \\
\hline Joint & $41(68.33)$ & - & - & - \\
\hline $\begin{array}{ll}\text { Members } & \\
\text { below } & 15 \\
\text { years } & \end{array}$ & $156(32.84)$ & - & - & - \\
\hline $\begin{array}{l}\text { Members } \\
\text { between 15- } \\
60\end{array}$ & $293(61.68)$ & - & - & - \\
\hline $\begin{array}{l}\text { Members } \\
\text { above } 60\end{array}$ & $26(5.40)$ & - & - & - \\
\hline $\begin{array}{l}\text { Average } \\
\text { family size }\end{array}$ & 7.91 & 19 & 3 & 0.46 \\
\hline \multicolumn{5}{|c|}{ Major occupation } \\
\hline Agriculture & $39(65.00)$ & - & - & - \\
\hline $\begin{array}{l}\text { Wage/Labou } \\
\mathrm{r}\end{array}$ & $2(3.33)$ & - & - & - \\
\hline $\begin{array}{l}\text { Trade/Busin } \\
\text { ess }\end{array}$ & $15(25.00)$ & - & - & - \\
\hline Service & $3(5.00)$ & - & - & - \\
\hline Remittance & $1(1.67)$ & - & - & - \\
\hline \multicolumn{5}{|l|}{ Land holding } \\
\hline $\begin{array}{l}\text { Owned Land } \\
\text { (Ropani) }\end{array}$ & 14.20 & - & - & - \\
\hline $\begin{array}{l}\text { Rented-in } \\
\text { (Ropani) }\end{array}$ & 0.67 & - & - & - \\
\hline $\begin{array}{l}\text { Rented-out } \\
\text { (Ropani) }\end{array}$ & 0.73 & - & - & - \\
\hline $\begin{array}{l}\text { Total land } \\
\text { (Ropani) }\end{array}$ & 15.53 & 80 & 1 & 1.79 \\
\hline $\begin{array}{l}\text { Total } \\
\text { cultivated } \\
\text { land } \\
\text { (Ropani) }\end{array}$ & 11.96 & 50 & 1 & 1.19 \\
\hline $\begin{array}{l}\text { Total maize } \\
\text { cultivated } \\
\text { land } \\
\text { (Ropani) }\end{array}$ & 5.81 & 30 & \begin{tabular}{|l|}
1 \\
\end{tabular} & 0.66 \\
\hline Income & 40541.67 & 150000 & 1500 & 3855.3 \\
\hline
\end{tabular}

${ }^{3}$ Individuals who can read and write 


\begin{tabular}{|l|l|l|l|l|}
\hline $\begin{array}{l}\text { from } \\
\text { Agriculture }\end{array}$ & & & & 3 \\
\hline $\begin{array}{l}\text { Income } \\
\text { from maize }\end{array}$ & 18991.67 & 90000 & 1000 & $\begin{array}{l}2225.2 \\
5\end{array}$ \\
\hline
\end{tabular}

Note: Figures in the parenthesis represent the percentage

\section{ii. Mostly affected parameters by climate change}

The most rated effect of climate change was reduced quality (3.67) followed by yield loss (3.48), diseases (3.27) and pest (3.13) as shown in Table 2. Climate change is deteriorating the quality of the product which can be attributed to the shift in flowering time and immature maturity or early maturity. In spite of rainfall during harvesting, hailstorm deteriorate the quality of the produce which ultimately results yield loss.

Table 2 Mostly affected parameters by climate change

\begin{tabular}{lll}
\hline Parameters & Values & Rankings \\
\hline Reduced quality & 3.67 & I \\
Yield loss & 3.48 & II \\
More diseases & 3.27 & III \\
More pests & 3.13 & IV \\
\hline
\end{tabular}

iii. Major factors affecting Maize production and productivity

iv. The major factor affected by climate change were more frequent droughts (4.02) followed by more severe drought (2.83), more frequent storms (2.65), unseasonal rains (2.22), and more intense storms (1.93) respectively as shown in table 3 . Western hills are receiving more frequent droughts at present context. These frequent droughts are affecting the maize production and productivity. Some of those droughts are quite severe.

Table 3 Majors factors affecting maize production and productivity

\begin{tabular}{lll}
\hline Parameters & Value & Ranking \\
\hline More frequent droughts & 4.02 & I \\
More severe droughts & 2.83 & II \\
More frequent storms & 2.65 & III \\
Unseasonal rains & 2.22 & IV \\
More intense storms & 1.93 & V \\
\hline
\end{tabular}

v. Farmers response to climate change

vi. The majority of the farmers do little or nothing to cope with the effects of climate change as shown in Table 4. Some farmers' intensified routine activities like pruning, fertilizing and pest control activities to cope with the negative consequences of climate change on their maize crops. Much of the farmers still have not gone for crop diversification to cope with the climate change.

Table 4 Farmers response to climate change

\begin{tabular}{|c|c|c|}
\hline Parameter & $\begin{array}{l}\text { Val } \\
\text { ues }\end{array}$ & $\begin{array}{l}\text { Ranki } \\
\text { ngs }\end{array}$ \\
\hline Do little or nothing & 2.67 & I \\
\hline $\begin{array}{l}\text { Intensify routine activities (pruning, } \\
\text { fertilizing, pest control etc.) }\end{array}$ & 2.23 & II \\
\hline $\begin{array}{l}\text { Specific adaptations (irrigation, improved } \\
\text { drainage, etc.) }\end{array}$ & 2.08 & III \\
\hline Diversify to other crops & 2.07 & IV \\
\hline
\end{tabular}

\section{vii. Sources of information on climate change}

The most of farmers obtained the information on climate change through radio $(78.3 \%)$ followed by TV $(13.3 \%)$, internet (5\%), Newspaper $(1.7 \%)$ and educational institutions nearby $(1.7 \%)$.

Table 5 Source of information on climate change

\begin{tabular}{ll}
\hline Sources & $\begin{array}{l}\text { Overall } \\
\text { Average }\end{array}$ \\
\hline Radio & $47(78.3)$ \\
TV & $8(13.3)$ \\
Internet & $3(5)$ \\
Newspaper & $1(1.7)$ \\
Education Institution & $1(1.7)$ \\
\hline
\end{tabular}

(Figures in the parenthesis represent the percentage)

\section{Farmer's trust on different information sources}

The relatively greater number of the farmers trusted on the media (4.93) followed by scientists, government sources, family member or friends, World Wide Fund, supplier and environmental organization respectively.

Table 6 Farmers' trust on different information sources

\begin{tabular}{lll}
\hline Sources & Values & Ranking \\
\hline Trust the media & 4.93 & I \\
Trust scientist & 4.77 & II \\
\hline
\end{tabular}




\begin{tabular}{lll}
\hline Trust government & 4.55 & III \\
Trust family member or a friend & 4.28 & IV \\
Trust on World Wildlife fund & 3.28 & V \\
Trust supplier & 3.05 & VI \\
an environment Trust & 2.83 & VII
\end{tabular}

\section{Required government interventions to combat climate change}

To cope with the effects of climate change first of all government needs to disseminate awareness about climate change using the most effective possible mediums. In addition to this government need to provide trainings on strategic planning at management level to cope with the climate change so that their capacity to cope with climate change will be strengthened. Training for trainers was rated least by the households.

Table 7 Need of different government effort cope with climate change.

\begin{tabular}{lllll}
\hline Parameters & & & $\begin{array}{l}\text { Val } \\
\text { ues }\end{array}$ & $\begin{array}{l}\text { Rank } \\
\text { ing }\end{array}$ \\
\hline $\begin{array}{l}\text { Information about adaptation } \\
\text { tools etc. }\end{array}$ & & & 4.23 & I \\
$\begin{array}{l}\text { Training for strategic planning } \\
\text { management level at }\end{array}$ & & & \\
$\begin{array}{l}\text { Training on project development and } \\
\text { execution (adaptive research) }\end{array}$ & & 3.03 & II \\
\begin{tabular}{l} 
Training of trainers \\
\hline
\end{tabular} & & 3.53 & IV \\
\hline
\end{tabular}

Farmers experience about different climatic parameters.

The figure 1 revealed that majority of the farmers (93.3\%) have experienced changes in temperature over the years. 91.7 percent individuals have experienced change in rainfall pattern and 86.7 percent have experienced changes in production over the years. The result revealed that only 36.7 percent of the individuals have tried the maize varieties recommended for Terai region in their land.

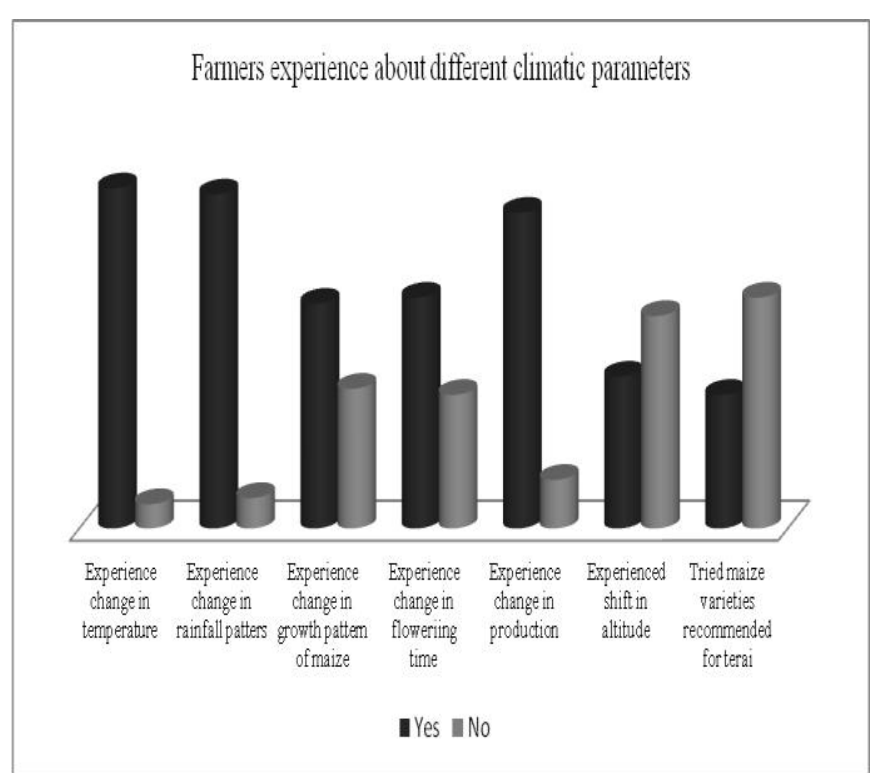

Fig.1: Farmers experience about different climatic parameters

Efforts carried out by the government and nongovernment organizations to cope with climate change

Table 8 reveals that government and non-governmental organizations have carried our surveys in those areas to cope with the climate change. Still other follow of activities are missing to carry on in those areas. Surveys are followed up by awareness/training events which are followed up by climate/meteorological studies. Widespread adaptation efforts have not been carried out in significant amount to cope with climate change.

Table 8 Different efforts carried out by different stakeholders

\begin{tabular}{lll}
\hline Parameters & Values & Ranking \\
\hline Surveys & 2.1 & I \\
Climate/meteorological studies & 1.6 & III \\
Awareness/training events & 1.9 & II \\
Adaptation pilot projects & 1.2 & IV \\
Widespread adaptation efforts & 1.0 & $\mathrm{~V}$ \\
\hline
\end{tabular}

\section{Factors affecting the knowledge on climate change}

Table 9 provides the result of binary logistic regression model to determine the most critical factors that influence the knowledge on climate change. The model's $\chi 2$ value of 23.45 and $\log$ likelihood ratio of -19.8703 indicate that all the variables in the model significantly influence the knowledge on climate change at $1 \%$. The Pseudo $\mathrm{R}^{2}$ $=0.3904$ means that 39.04 percentage of the knowledge on 
climate change is governed by the tabulated 4 explanatory variables i.e. the model fits 39.04 percent to the given data.

Table 9 Factors determining knowledge on climate change

\begin{tabular}{lll}
\hline $\begin{array}{l}\text { Know about climate } \\
\text { change }\end{array}$ & Coefficient & Standard error \\
\hline Gender of HHHs & -0.321 & 0.898 \\
Age of HHHs & $-0.190^{*}$ & 0.061 \\
Year of schooling & 0.038 & 0.116 \\
Agriculture as major & & \\
income source & $-1.434^{* * *}$ & 0.881 \\
Constant & 12.966 & 4.290 \\
\hline Number of Observation & 60 & \\
Chi-Square Value $(\chi 2)$ & 23.45 & \\
log likelihood ratio & -19.870 & \\
$\mathrm{R}^{2}$ & 39.04 & \\
\hline
\end{tabular}

Note: $*$ and $* * *$ denotes the level of significance at $10 \%$ and $1 \%$ respectively

The result revealed that age of $\mathrm{HHH}$ and Agriculture as a major income source were negatively significant at 10 percent level and 1 percent level respectively with negative sign. The result signifies that with the increase in age, the knowledge on climate change is decreasing as compared to the young people. Similarly individuals having agriculture as a major source of income have comparatively less knowledge on climate change as compared to the individuals with non-agriculture as major source of income. Khanal et al. (2017) stated that younger individuals and farmers having non-agriculture as major source of income are expected to have more knowledge and information about climate change and agronomic practices that they can use in response.

\section{CONCLUSION}

Climate change poses an increasing threat to the sustainability of agricultural production and livelihood strategies of poor and rural people worldwide. Agriculture is the primary source of food and is greatly dependent on weather and nature. It is primary mainstay of the majority of population and source of livelihood for most of the agriculture are heavily affected by the climate change and its implication in agriculture. Agriculture was the major occupation for the people of both rural municipalities. Farmers were gradually diverting towards other livelihood options like remittance, off farm activities, beside agriculture. Majority of farmers perceived changes in climate variability affected in maize production in recent years. Most of the farmer reported that there has been frequent drought and unseasonal rains. Frequent drought being the major problem possesses detrimental effect on the quality of maize. Farmers were deprived of modern technology and they mainly relied on radio, amongst others, for information about climate change. Change in temperature and rainfall pattern was experienced by majority of the farmers over the years. Minimal farmers' intensified routine activities like pruning, fertilizing and pest control practices to cope the discomforting consequences of climate change on maize crops. Government and non-governmental organizations carried surveys to analyze its' effect. Widespread adaptation efforts and their effective implement, at local and national levels, lags way behind the surging climate change. Empowering communities with information, technological skills, education and employment is the best way to address vulnerability. A location wise action-research is therefore necessary to identify and document climate change impacts and adaptation strategy. The local observations described above provide a clear direction for future research and for development planning and adaptation management programs in different ecological regions. Policy and program should be formulating holistic approach to mitigate climate change and improve livelihood of the local communities.

\section{ACKNOWLEDGEMENTS}

The first author is profoundly grateful to all the respondents of Baitaidi district of Nepal. He is indebted to, Prakash Kumar Pant, Officer of MoALMC, Government of Nepal for his mentorship and unstinting productive suggestions during study. They are also indebted to seniors and juniors who helped during study.

\section{REFERENCES}

[1] CBS. (2014). Statistical Information on Nepalese Agriculture. Central Bureau of Statistics, Kathmandu, Nepal.

[2] Dahal, N. (2006). Implications of climate change in Nepal: Some observations and opportunities. Paper presented at $23^{\text {rd }}$ Warden Seminar, November 2006 held in Pokhara, Nepal.

[3] Dale, R. F. (1983). Temperature perturbations in the Midwestern and South--eastern United States Raper and P. J. Kramer, Eds.) Pp.21-32. west view Press, Colorado, USA.

[4] FAOSTAT. (2010) Food and Agricultural Organization of the United Nations (FAO), FAO Statistical. 
[5] IPCC. (2007) Summary for policymakers. In: M. L. Parry, O. F. Canziani, J. P. Palutikof, P. J. Linden and C. E. Hanson (Eds.). Climate Change 2007: Impacts, adaptation and vulnerability. Contribution of working group II to the fourth assessment report of the Intergovernmental Panel on Climate Change (IPCC), Cambridge University Press, Cambridge, UK. pp. 7-22.

[6] IPPC, (2007). Intergovernmental Panel on Climate Change. $4^{\text {th }}$ Assessment Report: Climate Change

[7] Khanal, K. S, Dhungana. and S, Khanal. (2017). Perspective Response of Climate Change Impacts on Agricultural Crops in Sauraha-Pharsatikar VDC, Rupandehi District, Nepal. Int. J.Appl.Sci.Biotechnol. Vol 5(3): 345-355. DOI: http://dx.doi.org/10.3126/ijasbt.v5i3.18291.

[8] Lohani, S. N. (2007). Climate change in Nepal shall we wait until bitter consequences?. $\mathrm{T}$ he Journal of Agricultural Economics. 8(1).3845.

[9] Malla, G. (2008). Climate change and its impact on Nepalese agriculture. The Journal of Agriculture and Environment. Government of Nepal, Ministry of Agriculture and Cooperatives 9: 62-70.

[10] Malla, G. (2008). Climate change and its impact on Nepalese agriculture. The Journal of Agriculture and Environment. Government of Nepal, Ministry of Agriculture and Cooperatives 9: 62-70.

[11] MOAD. (2012). Selected indicators of Nepalese agriculture and population. Government of Nepal, Ministry of Agriculture Development, Agribusiness and Statistics Division, Kathmandu, Nepal. 2p.

[12] MoAD (2015). Statistical information on Nepalese agriculture (2014/2015). Agribusiness promotion and Statistics Division, Singh Durbar, Kathmandu, Nepal

[13] Pant, K.P. (2012). Climate Change and Food Security in Nepal. The Journal of Agriculture and Environment. 13. 919.

[14] Pokhrel, D.M. and B. Pandey. (2011). Climate Change Adaptation: Strategic Vision in Agriculture. The Journal of Agriculture and Environment. 12. 10412.

[15] Thomson, L. M. (1966). Weather variability, climate change and grain production. Science 188, 535-541. 